\title{
The Zeitgeist of "Financial Reporting Quality" Predictors: An Empirical Study among Local Governments (Districts) in Indonesia
}

\author{
Swarmilah Hariani ${ }^{1,2, *}$ A. Fakhrorazi ${ }^{1}$ \\ ${ }^{1}$ Ghazali Shafie Graduate School of Government (GSGSG), COLGIS, Universiti Utara Malaysia, Sintok, Malaysia \\ ${ }^{2}$ Faculty of Economics and Business, Universitas Mercu Buana, Indonesia
}

Received October 19, 2021; Revised November 25, 2021; Accepted December 22, 2021

\section{Cite This Paper in the following Citation Styles}

(a): [1] Swarmilah Hariani, A. Fakhrorazi, "The Zeitgeist of "Financial Reporting Quality" Predictors: An Empirical Study among Local Governments (Districts) in Indonesia," Universal Journal of Accounting and Finance, Vol. 10, No. 1, pp. 137-147, 2022. DOI: 10.13189/ujaf.2022.100115.

(b): Swarmilah Hariani, A. Fakhrorazi (2022). The Zeitgeist of "Financial Reporting Quality" Predictors: An Empirical Study among Local Governments (Districts) in Indonesia. Universal Journal of Accounting and Finance, 10(1), 137-147. DOI: 10.13189/ujaf.2022.100115.

Copyright $\mathrm{C} 2022$ by authors, all rights reserved. Authors agree that this article remains permanently open access under the terms of the Creative Commons Attribution License 4.0 International License

\begin{abstract}
The research investigated the relationship among FRQ, ICS, RPM, and COR as moderating variables. The research recommends that local governments should improve in the field of financial management and implement an effective internal control system. Aligning the research problem and objectives, this research adopted the agency theory for local government. This theory includes information asymmetry, where the agent has more information and understands more about the actual financial position than the principal. Modern democracies are based on a series of principal-agent relationships, which may lead to problems in the public sector. In this research, 257 qualified questionnaires were collected from local governments in Indonesia, using self-administered surveys. Furthermore, Partial Least Square-Structural Equation Modelling (PLS-SEM) technique was used for data analysis. The results showed that ICS, COR, and RPM have a positive relationship with FRQ, while the hypothesis that COR strengthens the effect of ICS on FRQ was rejected. High COR does not significantly improve the FRQ without being supported by a good ICS. With a high or low COR, the ICS will continue to be carried out properly by leaders and superiors. Therefore, a good COR does not significantly moderate the effect of the ICS on the FRQ. The quality of financial reports is the result of accounting activities that can provide financial information which can be understood by users and be used for
\end{abstract}

decision-making in the future.

Keywords Internal Control System and Regulation on Performance Measurement, Commitment to Organization, Financial Reporting Quality

\section{Introduction}

The consistently low performance of local governments (districts) in Indonesia regarding accountability reports and financial performance for 2015-2019 fell below 25\% of the total regional income or was included in the pattern of instructive relationships. This constitutes a problem, as the financial capacity of local governments is still heavily dependent on revenues and loans from the central government [1]. Meanwhile, the performance of local governments is intended to improve accountability, transparency, organizational management, and service improvement to society. Accountability is a significant mediator between quality financial reporting and organizational performance. Local governments in Indonesia have a problem with accounting employees aged 50 years having lower performance than younger employees, different educational backgrounds are not a significant obstacle because training is carried out to have 
the same knowledge and abilities. This is especially true for public organizations that aspire to enhance performance using a better-designed accountability system [2], [3]. Furthermore, accurate and precise recording of financial transactions increases performance effectiveness and accountability [4].

Local governments are required to follow the regulation criteria Number 71/ 2010 when drafting financial reports. Regional financial losses occur, alongside lack of revenue, administrative weakness, inefficiency, and ineffectiveness when not following the legislation. In many local governments, the current quality of financial reports does not meet the standards. These include Pematang Siantar, Padang Sidempuan, Medan, Labuhanbatu, North Labuhanbatu, Central Tapanuli, Nias, Padanglawas, Langkat, North Nias, Mandailing Natal, Pakpak Baarat and Karo, Simalungun, West Nias, South Nias, and Tanjungbalai, Karo, Mandailing Natal, and Pakpak Bharat [5]. Many districts with these problems in Indonesia are located in Indonesia; therefore, the financial reporting quality of the Indonesian government is low [6].

In Figure 1, the phenomenon of the gap in financial independence between regions (province, city, and districts) is very high, starting from 2015-2019. The percentage of financial independence shows a very striking difference between province, city, and districts. At the local government level (district) from 2015-2019, it can be seen that the level of regional independence is still very low, which is below $25 \%$, which is included in the instructive relationship pattern, meaning that the district government in Indonesia is unable to carry out regional autonomy financially, it can be seen in the percentage in figure 1, increase or decrease in numbers from 2015-2019. In 2015 , the independence ratio was $9.30 \%$, decreased to $8.64 \%$ in 2016. Meanwhile, in 2017, this level increased again to $11.71 \%$ but decreased to $10.52 \%$ in 2018 and $10.50 \%$ in 2019 . This indicates that the level of financial reporting on the island is low. In addition, local governments are not able to finance regional activities independently. This shows that the level of financial reporting of local governments (districts) is low compared to provinces and cities. In addition, local governments are not able to finance regional activities independently.

According to the Medan business newspaper (26 June 2019), there are several local governments which did not finance local activities were (e.g., Asahan, North Tapanuli, Toba Samosir, North Padanglawas, Samosir, Batubara, Humbang Hasundutan, South Tapanuli, Serdang Bedagai, Deli Serdang, Dairi and South Labuhanbatu) [7]. The newspaper (Medan, Gatra.com/March 30 2019) also reported that the local governments (district) that had not submitted financial reports to the BPK for auditing, including South Nias, West Nias, Tanjung Balai, Karo district, Mandailing Natal, and Pakpak Bharat [8]. Government financial reports were also weak, namely Pematang Siantar, Padang Sidempuan, Medan, Labuhanbatu, North Labuhanbatu, Central Tapanuli, Nias, Padanglawas, Langkat, North Nias, Mandailing Natal, Pakpak Bharat and Karo [8]. The newspaper "Rakyat Media, November 4, 2019, reported the performance of the Local Government (District) of Anambas to be poor. Several Indonesian local governments generally failed to comply with the law and operations of the financial report due to various points of weakness, which rendered it problematic and inadequate. There were problems such as lack of revenue and administrative irregularities. Therefore, the Audit Board of the Republic of Indonesia instructed the Anambas district government to recover the country's loss.

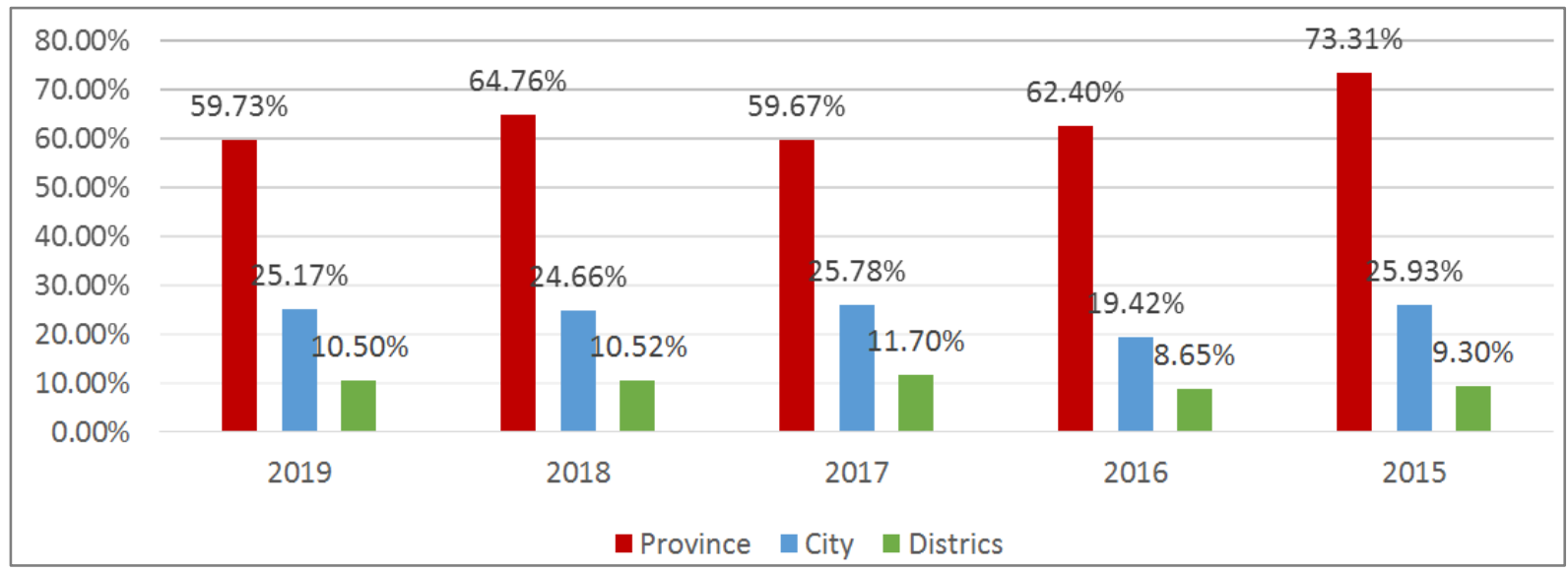

Figure 1. Independent Level in Local Government of Province, City and Districts 2015-2019 (Audit Board of the Republic of Indonesia, 2020) 
The local newspaper in South Bengkulu (district) stated fixed assets worth Rp. 35.48 billion whose whereabouts are unknown. Therefore, it was grouped into other assets, which led to problems in the internal control system and violations of laws and regulations. Furthermore, opinions of the local newspaper's newspaper opinions on South Bengkulu's financial report did not change [9], which constitutes a significant problem for local governments. The weaknesses in the accounting and financial reporting system include the lack of orderly preparation and application following government financial accountability report principles, such as the Government Accounting Standard No. 71/ 2010. This standard was established based on regulations [10], where local governments can administer their financial management [11].

Deviations and leaks are still found in the finance report, which shows that the quality of financial reporting is not yet standard [12]. There is a problem of lack of revenue and irregularities in the administration of state finance, which is a weakness of the local governments in Indonesia [13], [14]. The financial reports have decreased due to many errors in reporting from District Governments in Indonesia [15], [16]. Based on Law No. 15/ 2004 concerning the Audit of State Financial Management and Accountability in Indonesia, providing audit opinions to produce financial reporting quality are based on general criteria. These include the effectiveness of the internal control system, compliance with applicable laws and regulations, and compliance with Government Accounting Standards No. 71/ 2010 [17].

The contribution of this research is contributing to examine examining issues related to the financial reporting quality assessment in local governments. The results are expected to give input and feedback to prepare and evaluate accounting standards in developing, improving, and selecting the financial reporting quality policies in a local government. Furthermore, this research can also be used to evaluate the local government financial reporting quality and give provide motivation to the government related to using public funds and other entrusted assets. This is because it provides an overview of the consolidated state of affairs and resources and improves the characteristics of accountability, decision making, understanding, comparability, verification, and timeliness. It is an important element of financial reporting information, which enhances significant decisions.

\section{Literature Review}

The agency theory explains the agreement (contract) between the principal and agent, where the principal permits the agent to make decisions on their behalf [18]. Therefore, agency theory is the relationship between the principal and the agent [19]. This theory is used to ascertain how an individual delegates responsibility to others [20]. According to this theory, someone who delegates a job to which they are responsible is called principal, and individuals who accept jobs are called agents [21]. Furthermore, Indonesia's current local government believes that the courts have been convicted for misusing local revenue and spending budgets. This is likely due to a large legislative role in budgeting, especially at the planning or formulation stages of budget policy and approval. Allegedly, there was a budget allocation and estimation because of the personal interest of some politicians [22].

The internal control system is important in every organization because it directly affects the financial report quality issued to users. The managers in insurance companies should regularly review the internal control system and hire qualified staff for the internal audit department [23].

\section{Hypothesis 1: ICS positively affects $F R Q$}

Irrespective of organizational commitment, the internal control system may be carried out properly by the leadership and superiors. Therefore, good organizational commitment may not necessarily be able to moderate the influence of internal control on the quality of financial reporting [24]. Organizations without an existing internal control system are generally considered to be open to risk and may bring down an institution in a short time. This also brings the possibility of fraud and loss of organizational funds by staff, thereby damaging financial reports [25]. Meanwhile, internal control over the quality of financial reporting expresses a positive objective, especially when all parties in the organization involved comply with their duties. It enables the quality of financial reporting to be comparable, understandable, relevant, and reliable [26]. In addition, a good internal control system helps organizations prevent fraud, errors and minimize waste [27].

Furthermore, it is impossible to eliminate regulations that are impossible to stop, as they exist to improve the financial reporting quality [28]. Law enforcement is important because it enhances and guarantees financial reporting quality [29]. A country's legal and regulatory system significantly affects financial reporting quality but is yet to be explored in accounting literature. The country's regulations determine the quality of the annual reports [30].

\section{Hypothesis 2: ICS significantly influences $F R Q$ with COR as a moderator.}

The commitment to goals is crucial for manager productivity to determine whether the organization can achieve its goals [31]. High-performing organizations choose the best strategies for integrating their components, activities, core processes, and resources to support the achievement of the mission [32]. Commitment shows the 
employee's loyalty to the company reflected through continuous participation in decision-making, attention to members, and the prosperity of successful organizations [33]. Therefore, commitment to the organization is seen as employee loyalty to their employer [34]. Individuals' identification and involvement with a particular organization are more significant than perceived loyalty [35]. Commitment to the organization is significant when employees are more interested in maintaining work relationships [36].

Local government financial reports are an essential component for Indonesia to realize public financial management accountability [37]. Therefore, increasing demand for the implementation of public accountability has implications for management in government institutions to provide information to the public, which includes information about financial reports [38]. The function of information in financial reports will not have benefits if the presentation and delivery of financial information are unreliable and not timely [39].

\section{Hypothesis 3: COR positively affects $F R Q$}

Regarding the compliance with the regulation for financial reporting quality, the results are consistent with the reason that the financial reporting quality must be improved by an implemented regulation [40]. Regulations are impossible to eliminate, as they exist to improve the quality of financial reporting [28]. Law enforcement helps to increase and guarantee financial reporting quality [29]. One of the important factors that affect financial reporting quality that is yet to be explored in accounting literature is the country's legal and regulatory system. There are limited studies on the environmental laws and effects of regulation on quality financial reporting. This is because a country's laws play a very important role in establishing the quality of the company's annual report [30].

\section{Hypothesis 4: RPM positively affects $F R Q$}

In this research, based on agency theory, the relationship between ICS, RPM, COR, and FRQ in a theoretical model is shown in Figure 2.

\section{Data and Methodology}

The respondents amounted to 257 people from various positions such as head of accounting, senior and junior accounting which constitute the financial management in local governments (Districts) in Indonesia. Furthermore, data were collected through questionnaires delivered to the respondent's workplaces. This approach tends to have a higher response rate than sending a questionnaire by mail or post [41].

Table 1. Demographic Characteristics of the Respondents

\begin{tabular}{|c|c|c|c|}
\hline Demographic & Category & $\mathbf{n}$ & $\mathbf{\%}$ \\
\hline Gender & Male & 102 & 39.7 \\
\hline & Female & 155 & 60.3 \\
\hline Age & $<25$ & 40 & 15.57 \\
\hline & $25-37$ & 62 & 24.12 \\
\hline & $38-50$ & 121 & 47.09 \\
\hline Education & $>50$ & 34 & 13.22 \\
\hline & Bachelor Degree & 165 & 64.20 \\
\hline & $\begin{array}{c}\text { Master Degree or } \\
\text { Above }\end{array}$ & 92 & 35.80 \\
\hline Position & $\begin{array}{c}\text { Head of } \\
\text { Accounting }\end{array}$ & 87 & 33.85 \\
\hline & Senior Accounting & 92 & 35.80 \\
\hline & Junior Accounting & 78 & 30.35 \\
\hline
\end{tabular}

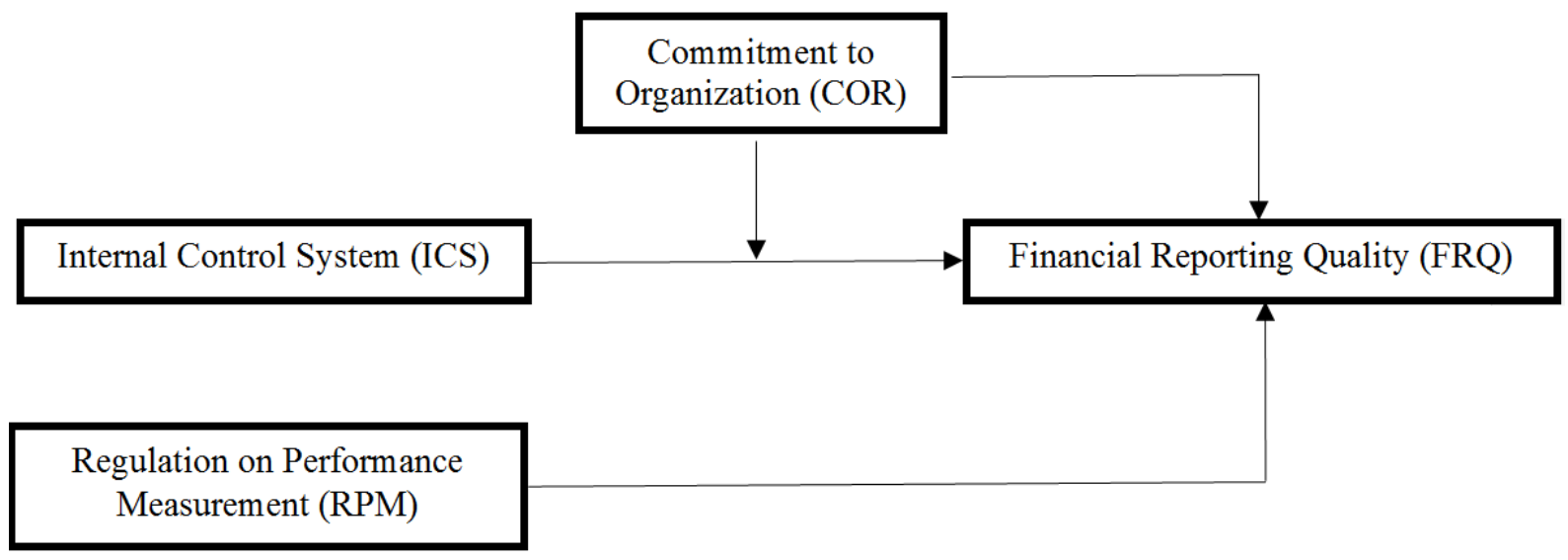

Figure 2. Theoretical Framework 
The demographic characteristics of the respondents in this study are the profiles of the 257 respondents who filled out this questionnaire. The characteristics of these respondents include gender, age, education, and position in local government in Indonesia. Male respondents were $102(39.7 \%)$, while female respondents were $155(60.3 \%)$. As for age, $40(15.57 \%)$ respondents were $<25$ years, 62 $(24.12 \%)$ were $25-37$ years, $121(47.09 \%)$ were $38-50$ years and $34(13.22 \%)$ were $>50$ years. People who got a Bachelor's Degree were as many as $165(64.20 \%)$ and Master's Degree or Above 92 (35.80\%). Positions in the Head of Accounting category were 87 (33.85\%), Senior Accounting 92 (35.80\%), and Junior Accounting 78 $(30.35 \%)$. The demographic characteristics of the respondents are given in Table 1.

The technique of data collection in this research is known as snowball sampling. First, 15 employees from several local governments in Indonesia who were willing to participate in the survey were identified. They, in turn, asked other groups and communities if they would like to be involved in this online survey and received 257 positive responses. The measurement items in the questionnaire were seven-point Likert scales and adapted from ICS 26 items [42]; RPM 5 items [43]; COR 15 item [44]; FRQ 4 items [45].

The Partial Least Square (PLS) with Structural Equation Modeling (SEM) was used to analyze data and test the validity of statistical conclusions [46]. Specifically, SmartPLS was used, one of the most common software with favorable terms, methodological options, and ease of use [47].

\section{Results}

The first stage of PLS-SEM evaluation was the model measurement. The model validity was established before conducting the hypothesis test and ensuring the efficiency of the instrument. The composite reliability was tested first because it is related to validity. The ideal composite reliability value should be above 0.7 [48]. Table 2 shows that the composite reliability value of COR, FRQ, ICS, RPM are above 0.7 and meet the convergent validity criteria.

Table 2. The result of Composite Reliability

\begin{tabular}{|c|c|c|}
\hline Model Construct & Item & $\begin{array}{c}\text { Composite } \\
\text { Reliability }\end{array}$ \\
\hline COR & 15 & 0.927 \\
\hline FRQ & 4 & 0.900 \\
\hline ICS & 26 & 0.990 \\
\hline RPM & 5 & 0.933 \\
\hline
\end{tabular}

Meanwhile, the convergent validity of this model should be tested by researchers. According to the guidelines [48], regarding the measurement of an element of convergent validity, for an acceptable convergent validity, the factor loading requires $<0.70$. The average variance extracted (AVE) has to be $>0.50$. Table 3 displays the convergent validity of the 4 variables. Based on table 2, the factor loading of COR, FRQ, ICS, RPM is greater than 0.7 with AVE above 0.5 ; hence, the convergent validity is met. Based on the tests carried out, it was observed that five indicators were declared invalid, with the value of outer loading $\geq 0.40$ but $<0.70$. Therefore, these indicators must be removed to review the results of the outer loading generated to ensure continuation with the next step [48]. With the removal of the invalid indicator, the test results obtained are shown in Table 3.

The discriminant validity falls under construct validity. Table 3 shows that the square root of the model constructs AVE was greater than the squared correlations. Therefore, the discriminant validity of the variable is met and recognized. 
The Zeitgeist of "Financial Reporting Quality" Predictors:

An Empirical Study among Local Governments (Districts) in Indonesia

Table 3. The result of Convergent Validity

\begin{tabular}{|c|c|c|c|}
\hline Model Construct & Measurement Items & Loading & AVE \\
\hline \multirow{15}{*}{$\mathrm{COR}$} & COR 1 & 0.842 & \multirow{15}{*}{$0.75 \mathrm{~s}$} \\
\hline & COR 2 & 0.981 & \\
\hline & COR 3 & 0.210 & \\
\hline & COR 4 & 0.881 & \\
\hline & COR 5 & 0.828 & \\
\hline & COR 6 & 0.834 & \\
\hline & COR 7 & 0.372 & \\
\hline & COR 8 & 0.877 & \\
\hline & COR 9 & 0.384 & \\
\hline & COR 10 & 0.840 & \\
\hline & COR 11 & 0.325 & \\
\hline & COR 12 & 0.424 & \\
\hline & COR 13 & 0.894 & \\
\hline & COR 14 & 0.806 & \\
\hline & COR 15 & 0.308 & \\
\hline \multirow{4}{*}{ FRQ } & FRQ 1 & 0.769 & \multirow{4}{*}{0.69} \\
\hline & FRQ 2 & 0.829 & \\
\hline & FRQ 3 & 0.800 & \\
\hline & FRQ 4 & 0.926 & \\
\hline \multirow{26}{*}{ ICS } & ICS 1 & 0.921 & \multirow{26}{*}{0.796} \\
\hline & ICS 2 & 0.942 & \\
\hline & ICS 3 & 0.878 & \\
\hline & ICS 4 & 0.869 & \\
\hline & ICS 5 & 0.898 & \\
\hline & ICS 6 & 0.953 & \\
\hline & ICS 7 & 0.836 & \\
\hline & ICS 8 & 0.929 & \\
\hline & ICS 9 & 0.877 & \\
\hline & ICS 10 & 0.862 & \\
\hline & ICS 11 & 0.915 & \\
\hline & ICS 12 & 0.926 & \\
\hline & ICS 13 & 0.894 & \\
\hline & ICS 14 & 0.917 & \\
\hline & ICS 15 & 0.960 & \\
\hline & ICS 16 & 0.841 & \\
\hline & ICS 17 & 0.814 & \\
\hline & ICS 18 & 0.861 & \\
\hline & ICS 19 & 0.833 & \\
\hline & ICS 20 & 0.850 & \\
\hline & ICS 21 & 0.899 & \\
\hline & ICS 22 & 0.994 & \\
\hline & ICS 23 & 0.835 & \\
\hline & ICS 24 & 0.880 & \\
\hline & ICS 25 & 0.938 & \\
\hline & ICS 26 & 0.845 & \\
\hline \multirow{5}{*}{ RPM } & RPM 1 & 0.782 & \multirow{5}{*}{0.737} \\
\hline & RPM 2 & 0.869 & \\
\hline & RPM 3 & 0.955 & \\
\hline & RPM 4 & 0.843 & \\
\hline & RPM 5 & 0.835 & \\
\hline
\end{tabular}


Table 4. Discriminant Validity of Constructs

\begin{tabular}{|c|c|c|c|c|}
\hline Constructs & COR & FRQ & ICS & RPM \\
\hline COR & 0.705 & & & \\
\hline FRQ & 0.661 & 0.833 & & \\
\hline ICS & 0.611 & 0.710 & 0.892 & \\
\hline RPM & 0.307 & 0.503 & 0.246 & 0.859 \\
\hline
\end{tabular}

The R2 values show the quality of the variable reflected by the structural model specifications. The approved value of $\mathrm{R} 2$ is between 0 and 1 [48].

The communality and redundancy value can be explored as additional structural model specification pillars. The ideal structural model value of communality should be greater than 0.4 and lower than 0.10 for redundancy. Table 4 displays the values of the structural model specification variables.

As shown in Table 4, all constructs have met the criteria for communality validity. The redundancy validity was approved even though the FRQ value was higher than 0.1 concerning $\mathrm{R} 2$ value and communality. Therefore, all constructs met the structural model validity criteria.

Table 5. Structural Model Specification

\begin{tabular}{|c|c|c|c|}
\hline Constructs & R2 & Communality & Redundancy \\
\hline COR & Predictor & 0.759 & Predictor \\
\hline FRQ & 0.672 & 0.694 & 0.466 \\
\hline ICS & Predictor & 0.796 & Predictor \\
\hline RPM & Predictor & 0.737 & Predictor \\
\hline
\end{tabular}

Hypothesis testing is also referred to as bootstrapping technology. Figure 4 shows the PLS Bootstrapping for the research model.

This study has four hypotheses, which were tested using Partial Least Square (PLS). As shown in the Hypothesis Testing in Table 6, ICS has a statistically positive effect on the FRQ (H1), ICS has a statistically positive effect on the FRQ, COR strengthens the effect of ICS on FRQ is rejected (H2), COR has a statistically positive effect on the FRQ (H3) and RPM has a statistically positive effect on the FRQ (H4).

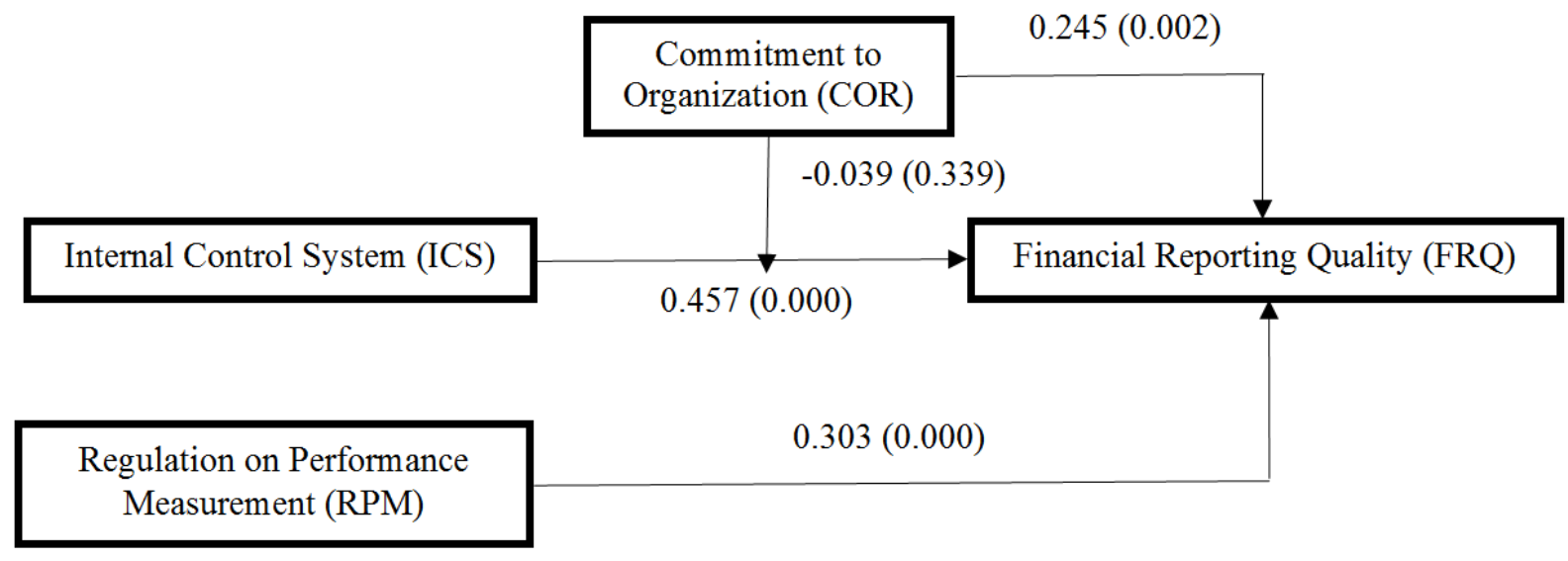

Figure 3. The Structural Model for Individual Latent Variables

Table 6. Hypothesis Testing

\begin{tabular}{|c|c|c|c|c|c|c|}
\hline Hypothesis & Relationship & $\begin{array}{c}\text { Original } \\
\text { Sample }\end{array}$ & $\begin{array}{c}\text { Standard } \\
\text { Deviation }\end{array}$ & T Statistics & P Values & Supported \\
\hline H1 & ICS -> FRQ & 0.457 & 0.049 & 9.340 & 0.000 & Yes \\
\hline H2 & COR X ICS -> FRQ & -0.039 & 0.040 & 0.956 & 0.339 & No \\
\hline H3 & COR -> FRQ & 0.245 & 0.080 & 3.070 & 0.002 & Yes \\
\hline H4 & RPM -> FRQ & 0.303 & 0.056 & 5.432 & 0.000 & Yes \\
\hline
\end{tabular}




\subsection{Relationship between Internal Control System (ICS) and Financial Reporting Quality (FRQ)}

The effect of ICS on FRQ had a statistical value of 9,340 and a p-value of 0.000 . The P-value was lesser than $\alpha=0.05$; therefore, it has a statistically positive effect on the FRQ. The research (H1) is true that good ICS improves the FRQ, and ICS plays an important role in meeting the objectives of managing public finances, the state economy, making informed decisions, and minimizing corruption [26]. The implementation of the ICS was able to improve the reliability and objectivity of information, prevent inconsistencies, and facilitate the process of auditing financial reports to create FRQ because ICS is the basis of the entire process of securing and managing state assets, and every government institution must encourage the availability of all state financial managers who have a strong awareness of the importance of internal system enforcement [49]. An effective internal control system will assure that the preparation of FRQ is consistent with recognized accounting principles and standards [50]. It is intended to give adequate assurance to achieve effective and efficient management based on Government Regulation No. 60/2008, among others: control environment, risk assessment, control activities, information and communication, and monitoring. This means that the better the implementation of the ICS implementation element, the better the quality of the local government financial reports produced. The implementation of the ICS can improve the reliability and objectivity of information, prevent inconsistencies, and facilitate the process of auditing financial statements to create FRQ [49], [51]. This research is in line with [52],[23].

\subsection{Internal Control System (ICS) effect on Financial Reporting Quality (FRQ) to be moderated Commitment to Organization (COR)}

The effect of ICS on FRQ using COR as a moderator had a statistical value of 0.956 and a p-value of 0.339 . The P-value was greater than $\alpha=0.05$; statistically, COR does not moderate the effect of ICS on FRQ. Therefore, the hypothesis $(\mathrm{H} 2)$, which states that COR strengthens the effect of ICS on FRQ, is rejected. High COR is not enough to improve the FRQ without being supported by a good ICS. The COR failed to moderate the effect of ICS on the FRQ. Whether high or low COR, the ICS will continue to be carried out properly by leaders and superiors; therefore, a good COR may not necessarily moderate the effect of system COR and ICS on the FRQ [24]. To minimize fraud, employees need to consider the quality of Internal Control and perceived fairness of organizational rules and policies, most of which are sourced from controlled finance or the chief accountant of an organization to achieve FRQ [53].

In an organization, the roles and policies taken by top management are very decisive because every work done by subordinates only follows what is ordered by the superior or pleases the boss. Therefore, if they are not in line with the policies taken by the leadership, good SPI and COR will certainly not improve the FRQ produced. Local governments must also always motivate employees in the finance department so that competent human resources have high COR because they can improve the financial performance of local governments in preparing FRQ. Employees or subordinates who have a high commitment to their organization will use the budget to assist leaders in achieving organizational goals. Employees will tend to avoid and minimize the occurrence of budget slack because subordinates who have high COR will seek to develop the organization in a better direction. Subordinates with low COR will use budget planning and implementation to achieve personal interests, creating budget slack. The level of COR, the internal control system, will still be carried out properly by the leadership and superiors, so that good COR may not necessarily be able to moderate the influence of the COR, ICS on the FRQ. This research is in line with [24].

\subsection{Commitment to Organization (COR) and Financial Reporting Quality (FRQ)}

The influence of COR on FRQ had a statistical value of 3.070 and a $\mathrm{p}$-value of 0.002 . The P-value was smaller than $\alpha=0.05$; therefore, it affects the FRQ statistically. The hypothesis (H3), which states that COR positively affects FRQ, is accepted. These results prove that when an employee is highly committed to achieving organizational goals, the output will be better, and vice versa, related to financial reports produced by regional work units. The Local government's commitment to financial management will improve the quality of the report as per the regulatory standards. This commitment involves job attitudes or beliefs that reflect the relative strength of partisanship and involvement of individuals in organizations in particular [54]. Commitment shows the enthusiasm to work hard, utilize energy and time on a job or activity. Therefore, it involves more than passive loyalty and includes active relationships and aspiration to contribute to the organization effectively [55]. Contribution in the management of state finances is to producing financial reports quality for the presentation, disclosure of all financial transactions, and control of all assets to get a good opinion from the auditor.

\subsection{Relationship between Regulation on Performance Measurement (RPM) and Financial Reporting Quality (FRQ)}

The influence of RPM on FRQ had a statistical value of 5.432 and a $p$-value of 0.000 . The P-value was smaller than $\alpha=0.05$ and had a statistically positive effect on the FRQ. Therefore, hypothesis (H4), which states that RPM 
positively affects the FRQ, is accepted. The results are consistent with why the FRQ must be improved by implementing regulations [40]. Regulations are impossible to eliminate and exist to improve the FRQ [28] Law enforcement is important because it enhances and guarantees FRQ [29]. There is no need to be afraid of stricter regulations such as laws, and this is related to transparency; it can allow the company/organization to be high-performing to show its performance, increasing its competitive advantage [56]. It does not matter whether it is against other relevant laws and regulations. This transparency allows promoting access to information, and thereby increasing citizens' trust [57]. Transparency has become the main instrument of regulation. Legislators require public institutions to disclose information about their activities that affect public welfare. Transparency in the laws and regulations is required when governing accounting services to these citizens [58]. The need for financial transparency was first mentioned in Law 17/ 2003 concerning State Finance, confirmed as a significant factor in the state finances accountability. Government transparency in the state finances management and accountability is important. The public disclosure of financial reports shows "transparency" and "accountability" of state financial management. The regulation explains several reasons that require public bodies to be transparent in terms of information to citizens, guarantee citizens' rights, know plans for making public policies, public policy programs, and public decision-making processes, as well as the reasons for making a public decision. This research is in line with [57], [59].

\section{Conclusions and Suggestions}

Overall, this research investigated the relationship between FRQ, ICS, RPM, and COR as moderating variables. From the results, the proposed model provided insight and understanding of the relationship between each variable that affects financial reporting quality. Furthermore, the model showed a moderating effect of COR on the relationship between ICS and FRQ. This research recommends that local governments should improve in the field of financial management and implement an effective internal control system. This provides sufficient confidence for stakeholders that local government financial management was carried out in a transparent and accountable manner. Furthermore, commitment to the organization becomes an important part because it plays a role in change, implementation, and decision-making. It can increase discipline in accountability and challenges for local governments to improve the quality of financial reports. The public still pays attention to or demands financial reporting quality, which is used as a service and community need. Thus, to realize the performance required by the community requires financial quality and accounting management. Local governments must be committed to encouraging their human resources to comply with regulations and perform to produce quality financial reports. This study also found that the local government in Indonesia had problems with accounting employees aged $\geq 50$ years having lower performance compared to younger employees. Different educational backgrounds are not a significant obstacle because training is carried out to have the same knowledge and abilities.

\section{REFERENCES}

[1] Korompot, R., \& Warongan, J., "Analysis of Financial Performance in the Government of North Sulawesi. Accountability", vol. 6, no. 2, pp. 9-19, 2017. DOI: 10.32400/ja.17755.6.2.2017.9-19.

[2] Crawford, L., Morgan, G. G., \& Cordery, C. J, "Accountability and not-for-profit organisations: Implications for developing international financial reporting standards. Financial Accountability \& Management", vol. 34, no. 2, pp. 181-205, 2018. DOI: 10.1111/faam. 12146 .

[3] Tran, Y. T., Nguyen, N. P., \& Hoang, T. C., "The role of accountability in determining the relationship between financial reporting quality and the performance of public organizations: Evidence from Vietnam." Journal of Accounting and Public Policy, vol. 40, no. 1, pp. 1-7, 2020. DOI: 10.1016/j.jaccpubpol.2020.106801.

[4] Patton, J. M., “Accountability and Governmental Financial Reporting." Financial Accountability and Management, vol. 8, no. 3, pp. 165-180. 1992. DOI: 10.1111/j.1468-0408.19 92.tb00436.x.

[5] Putra TJ., "Only 17 Local Governments Received WTP Opinions from the BPK in North Sumatra". Indonesia News, https://www.gatra.com/detail/news/424494/economy/hany a-17-pemda-yang-terima-opini-wtp-dari-bpk-di-sumut (Accessed 24.10, 2021).

[6] Fizriyani, W., "IAI The Quality of Government Financial Reporting is Low." Indonesia News, https://republika.co.id /berita/p879mh335/iai-nilai-kualitas-pelaporan-keuangan-p emerintah-rendah (Accessed 24.10, 2021).

[7] Simamora, E., "17 districts/ city LKPD in North Sumatra Win WTP”. Indonesia News, https://medanbisnisdaily.com /news/online/read/2019/06/26/79076/17_lkpd_kabupaten_ kota_di_sumut_raih_wtp/ (Accessed 24.10, 2021).

[8] Putra., "Late Submitting LKPD, 6 Local Governments Are Confirmed Not to Get WTP". Indonesia News, https://www.gatra.com/detail/news/405182-Terlambat-Ser ahkan-LKPD-6-Pemda-Dipastikan-Tidak-Dapat-WTP (Accessed 24.10, 2021).

[9] Arif, A., "BPK Finds 8.77 billion in the Financial Report of the South Bengkulu Regency Government". Indonesia News,

https://www.nusantaraterkini.com/bpk-temukan-8-77-milia r-pada-laporan-keuangan-pemerintah-kabupaten-bengkulu- 
selatan (Accessed 24.10, 2021).

[10] Nurlis, \& Yudiati, W., "The Influence of Internal Control Effectiveness, Information Technology Utilization and Human Resources Competence on Local Government Financial Reporting Quality (Survey on SKPD Banten Provincial Government and Serang City)." Research Journal of Finance and Accounting, vol. 8, no. 12, pp. 111124. 2017.

[11] Veronica Tibiletti, Pier Luigi Marchini, Valter Gamba, Dina Lucia Todaro, "The Impact of COVID-19 on Financial Statements Results and Disclosure: First Insights from Italian Listed Companies," Universal Journal of Accounting and Finance, vol. 9, No. 1, pp. 54 - 64, 2021. DOI: 10.13189/ujaf.2021.090106.

[12] Ochuodho, H., \& Ngaba, D., "Revenue Administration Strategies and Financial Performance of Kisumu County." International Journal of Economics, Business and Management ResearchVol. 4, no. 12. pp. 230-251. 2020.

[13] Mir, M., Harun, H., \& Sutiyono, W., "Evaluating the Implementation of a Mandatory Dual Reporting System: The Case of Indonesian Local Government." Australian Accounting Review, vol. 29, no. 1, pp. 80-94. 2019. DOI: 10.1111/auar.12232.

[14] Setyawan, W., \& Gamayuni, R. R., "The Quality of Financial Reporting and Internal Control System before and after the Implementation of E-budgeting in Indonesia Local Government." Asian Journal of Economics, Business, and Accounting, vol. 14, no. 3, pp. 22-31. 2020. DOI: 10.9734/ajeba/2020/v14i330194.

[15] Aswar, K., "Assessing the impact of influencing factors on the quality of local government financial statements." Pressacademia, Tran, vol. 7, no. 1, pp 1-8. 2020. DOI: 10.17261/pressacademia.2020.1176.

[16] Irwan T, R., Clark, C., \& Wickremasinghe, G., "Assessing Financial Condition of Local Government in Indonesia: An Exploration." Public and Municipal Finance, vol. 1, no. 2, 2012. Pp 37-50.

[17] Furqan, A. C., Wardhani, R., Martani, D., \& Setyaningrum, D., "The effect of audit findings and audit recommendation follow-up on the financial report and public service quality in Indonesia." International Journal of Public Sector Management, vol. 33, no. 5, pp. 535-559. 2020. DOI: 10.1108/IJPSM-06-2019-0173.

[18] Jensen, C., \& Meckling, H., "Theory of The Firm: Managerial Behavior, Agency Costs and Ownership Structure." Journal of Financial Economics, vol. 3, no. 3, pp 305-360. 1976

[19] Douma, S. W., \& Schreuder, H., "Economic approaches to organizations." 4th ed. Harlow, England; New York: Financial Times/Prentice Hall, 2008 xvii, 416 p.: ill.; $25 \mathrm{~cm}$. 2002.

[20] Eugene F. Fama., "Agency Problems and the Theory of the Firm." Journal of Political Economy, vol. 88, no. 2, pp. 288-307. 1980

[21] Welbourne, T., \& Cyr, L., "Agency Theory Implications for Strategic Human Resource Management: Effects of CEO Ownership, Administrative HRM, and Incentive Alignment on Firm Performance." In CAHRS Working Paper Series. 1996.
[22] Mauro, P., "Corruption and the composition of government expenditure." Journal of Public Economics, vol. 69, no. 2, pp. 263-279. 1998. DOI:10.1016/S0047-2727(98)00025-5.

[23] Owolabi, S. A., \& Oluwadamilola, O. A., "Internal Control Systems and Quality of Financial Reporting in Insurance Industry in Nigeria." Journal of Finance and Accounting, vol. 8, no. 5, pp. 218-226. 2020. DOI: 10.11648/j.jfa.20200805.12.

[24] [24] Ikrar, N. B., "Accounting Analysis Journal the Effect of Internal Control Systems, Accounting Systems on the Quality of Financial Statements Moderated by Organizational Commitments." Accounting Analysis Journal, vol. 7, no. 2, pp. 127-134. 2018. DOI: 10.15294/aaj.v7i2.20616.

[25] Uwaoma, I., \& Ordu, P. A., "The Impact of Internal Controls on Financial Management: A Case of Production Companies in Nigeria." International Journal of Economics, Commerce and Management United Kingdom, vol. 12, no. 12, pp 103-132. 2015.

[26] Agbenyo, W., Jiang, Y., \& Cobblah, P. K., “Assessment of Government Internal Control Systems on Financial Reporting Quality in Ghana: A Case Study of Ghana Revenue Authority." International Journal of Economics and Finance, vol. 10, no. 11, pp. 40-50. 2018. DOI: 10.5539/ijef.v10n11p40.

[27] Ahmed, A., "Internal control systems \& its relationships with the financial performance in telecommunication companies a case study of Asiacell." International Journal of Scientific and Technology Research, vol. 7, no. 11, pp. 82-88. 2018. DOI: 10.29358/sceco.v0i28.416

[28] Greenwood, M. J., Baylis, R. M., \& Tao, L., Regulatory incentives and financial reporting quality in public healthcare organizations. Accounting and Business Research, vol. 47, no. 7, pp. 831-855. 2017. DOI: 10.1080/00014788.2017.1343116.

[29] Christensen, H. B., Liu, L. Y., \& Maffett, M., "Proactive financial reporting enforcement and shareholder wealth." Journal of Accounting and Economics, vol. 69, no. 2, pp. 1-52. 2019. DOI: 10.1016/j.jacceco.2019.101267.

[30] Kaur, T., \& Goel, A., "Impact of Changes in Regulatory Framework on Financial Reporting Quality: A Study of S\&P CNX Nifty Companies." IUP Journal of Accounting Research \& Audit Practices, vol. 16, no. 3, pp. 21-33. 2017.

[31] Bone, H., "The Effect of Organizational Citizen Behavior on Organizational Commitment: Evidence from Local Government Accountant." European Journal of Social Sciences, vol. 56, no. 2. pp. 238-249. 2018.

[32] Muda, I., Wardani, D. Y., Erlina, Maksum, A., Lubis, A. F., Bukit, R., \& Abubakar, E., "The influence of human resources competency and the use of information technology on the quality of local government financial report with regional accounting system as an intervening." Journal of Theoretical and Applied Information Technology, vol. 95, no. 20, pp. 5552-5561. 2017.

[33] Arthur, N., Chen, H., \& Tang, Q., "Corporate ownership concentration and financial reporting quality: International evidence." Journal of Financial Reporting and Accounting, vol. 17, no. 1, pp. 104-132. 2019. DOI: 10.1108/JFRA-07-2017-0051.

[34] Obedgiu, V., Bagire, V., \& Mafabi, S., "Examination of 
organizational commitment and organizational citizenship behavior among local government civil servants in Uganda." Journal of Management Development, vol. 36, no. 10, pp. 1304-1316. 2017. DOI:

10.1108/JMD-12-2016-0279.

[35] Davis, K., \& Newstron, J. W., "Human Behavior at Work. 2001. McGraw-Hill Publishers.

[36] Khalip, N., "A Three-Component Conceptualization of Organizational Commitment." International Journal of Academic Research in Business and Social Sciences, vol. 6, no.12, pp. 16-23. 2016. DOI: 10.6007/ijarbss/v6-i12/2464.

[37] Adiputra, I. M. P., Utama, S., \& Rossieta, H., "Transparency of local government in Indonesia." Asian Journal of Accounting Research, vol. 3, no.1, pp. 123-138. 2018. DOI: 10.1108/ajar-07-2018-0019.

[38] Hoque, Z., \& Moll, J., "Public sector reform - Implications for accounting, accountability, and performance of state-owned entities - an Australian perspective." International Journal of Public Sector Management, vol. 14 No. 4, pp. 304-326. 2017.

[39] Otniel, S., \& Sagrim, Y., "Impact of Human Resources Development on Organizational Financial Performance and Its Impact on Good Government Governance." International Journal of Economics and Financial Issues, vol. 9, no. 5, pp. 29-37. 2019. DOI: 10.32479/ijefi.8508.

[40] K. Nkundabanyanga, S., Tauringana, V., Balunywa, W., \& Naigo Emitu, S., "The association between accounting standards, legal framework and the quality of financial reporting by a government ministry in Uganda." Journal of Accounting in Emerging Economies, vol. 3, no. 1, pp. 6581. 2013. DOI: $10.1108 / 20440831311287709$.

[41] Hartono, J. "Guidance for Survey Study with Questionnaire." 2013. BPFE Yogyakarta.

[42] Yakubu, Ibrahim Nandom and Alhassan, Mohammed Mubarik and Iddrisu, Nasiru Alhassan and Adam, J. and S., \& Rahman, M., "The Effectiveness of Internal Control System in Safeguarding Assets in the Ghanaian Banking Industry." International Journal of Management and Commerce Innovations, vol. 5, no. 1, pp. 544-557. 2017.

[43] Samrudha Nayak, B. C. M. Patnaik, Ipseeta Satpathy, "Reflections on Implementation of International Financial Reporting Standards (IFRS) in the Indian Banking Industry," Universal Journal of Accounting and Finance, vol. 8, No. 4, pp. 148 - 152, 2020. DOI: 10.13189/ujaf.2020.080407.

[44] Ashman, I., "An investigation of the British organizational commitment scale: A qualitative approach to evaluating construct validity." Management Research News, vol. 30, no. 1, pp. 5-24. 2007. DOI:10.1108/01409170710724269.

[45] Mustapha, M., Ku Ismail, K. N. I., \& Ahmad, H. N., "Professionalism, competency and financial reporting quality: A perception of director of finance in a changing public sector reporting standard." Jurnal Pengurusan, vol. 57, pp. 1-19. 2019. DOI:

10.17576/pengurusan-2019-57-07.

[46] Cook, T. D., \& Campbell, D. T., "Quasi-Experimentation: Design and Analysis Issues for Field Settings." 1979. Houghton Mifflin.
[47] Ringle, C. M., Wende, S., \& Will, A., "SmartPLS 2.0 M3 (beta)". 2005. Hamburg: University of Hamburg.

[48] Hair, J., Hult, G. T. M., Ringle, C. M., \& Sarstedt, M., “A primer on partial least squares structural equation modeling (PLS-SEM)." In International Journal of Research \& Method in Education 2nd ed., vol. 38, no. 2. 2017. Sage. DOI: $10.1080 / 1743727 x .2015 .1005806$

[49] Goode, K. A. B., Newton, N. J., \& Thompson, A. M., "Business strategy, internal control over financial reporting, and audit reporting quality." Auditing, vol. 36, no. 4, pp. 49-69. 2017. DOI: 10.2308/ajpt-51693.

[50] Al-Hashimi, A. M., "Transparency of government financial reporting: A case study of local government financial reporting in Iraq." International Journal of Innovation, Creativity, and Change, vol. 10, no. 6, pp. 372-393. 2019.

[51] Alharbi, M. S. A., "The Effectiveness of the Implementation of Internal Control in Kuwaiti Shareholding Companies." International Journal of Academic Research in Accounting, Finance and Management Sciences, vol. 7, no. 4, pp. 232-241. 2017. DOI: $10.6007 /$ ijarafms/v7-i4/3541.

[52] Indriasih, D., "The Effect of Government Apparatus Competence and the Effectiveness of Government Internal Control Toward the Quality of Financial Reporting in Local Government." Research Journal of Finance and Accounting, vol. 5 , no. 20 , pp. 38-47. 2014.

[53] Rae, K., \& Subramaniam, N., "Quality of internal control procedures: Antecedents and moderating effect on organisational justice and employee fraud." Managerial Auditing Journal, vol. 23, no. 2, pp. 104-124. 2008. DOI: $10.1108 / 02686900810839820$.

[54] Girardi, \& Burr., "Intellectual Capital: More Than the Interaction of Competence \& Commitment." Australian Journal of Management Sydney, p.77-78. 2002.

[55] Mowday, R., R. S., \& Porter, L., "The Measurement of Organization Commitment. Journal of Vocational Behavior, vol. 14, pp. 224-247. 1979.

[56] Kinderman, D., "The tenuous link between CSR performance and support for regulation: Business associations and Nordic regulatory preferences regarding the corporate transparency law 2014/95/EU". Business and Politics, vol. 22, no. 3, pp. 1-36. 2019. DOI: 10.1017/bap.2019.19.

[57] Grimmelikhuijsen, S., Herkes, F., Leistikow, I., Verkroost, J., de Vries, F., \& Zijlstra, W. G., "Can decision transparency increase citizen trust in regulatory agencies? Evidence from a representative survey experiment". Regulation and Governance, vol. 15, no. 1, pp. 17-31. 2021 DOI:10.1111/rego.12278.

[58] Bajra, U., \& Cadez, S., "Audit committees and financial reporting quality: The 8th EU Company Law Directive perspective". Economic Systems, vol. 42, no. 1, pp. 151163. 2018. DOI: 10.1016/j.ecosys.2017.03.002.

[59] Puron-Cid, G., Reddick, C. G., \& Ganapati, S., "Public value of online financial transparency: Financial sustainability and corruption of public officials in the US state governments. International Journal of Public Sector Management, vol. 32, no. 5, pp. 511-533. 2019. DOI: 10.1108/IJPSM-03-2018-0073. 